\title{
Assessment of Umbilical Cord Milking on the Outcome of Term and Preterm Infants, Controlled Clinical Trial
}

\author{
Amal M Elshahat ${ }^{1}$, Zakia M Ibrahim ${ }^{1}$, Mohamed A Metawie ${ }^{2}$, Dalia Shams ${ }^{1}$ and Omima T Taha ${ }^{1 *}$ \\ ${ }^{1}$ Department of Obstetrics and Gynecology, Faculty of Medicine, Suez Canal University, Egypt \\ ${ }^{2}$ Department of Obstetrics and Gynecology, Faculty of Medicine, Port Said University, Egypt
}

*Corresponding author: Omima T Taha, Department of Obstetrics and Gynecology, Faculty of Medicine, Suez Canal University, Egypt.

\begin{abstract}
Background: Early cord clamping and cutting of the umbilical cord at birth may contribute to anemia in infancy thus it can deprive the infant of 60 to $100 \mathrm{ml}$ of whole blood representing $30-50 \mathrm{mg} / \mathrm{kg}$ of iron. The umbilical cord milking is a safe technique.
\end{abstract}

Aim of the study: The aim of the study to assess the effects of umbilical cord milking as compared with early cord clamping on hematological parameters (hemoglobin, packed cell volume, bilirubin and ferritin) among term and near term neonates.

Materials \& methods: This study was carried out as randomized, controlled clinical trial. The subjects were divided randomly into two groups ( 200 neonates who the cord was milked after cutting and clamping at $25 \mathrm{~cm}$ from the umbilicus as a study group and 200 neonates who were received early cord clamping without milking as a control group) in term and near term infants.

Results: the hemoglobin level significantly increased in study group at 12,48 hours and 6 weeks of birth $(16.9,16.9 \& 15.5 \mathrm{gm} / \mathrm{dl})$ as compared with control group $(16.2,16.2 \& 15.0 \mathrm{gm} / \mathrm{dl})$ and serum ferritin level significantly increased in study group at 6 weeks of birth $(135.4 \mu \mathrm{g} / \mathrm{ml})$ as compared with control group $(128.8 \mu \mathrm{g} / \mathrm{ml})$. The hematocrit level at 12 and 48 hours after birth was significantly higher in study group (p=0.016). Serum bilirubin was slightly elevated in study group but there were not any infants of them needed phototherapy.

Conclusions: Umbilical cord milking improved hemoglobin and iron status in term and near term neonates.

Keywords: Delayed cord clamping; Term and preterm; early cord clamping; Umbilical cord milking

\section{Introduction}

Current evidences suggest that the practice of immediate clamping and cutting of the umbilical cord at birth may contribute to anemia in infancy [1]. Immediate clamping can deprive a full term infant of 60 to $100 \mathrm{ml}$ of whole blood representing 30-60 mg/ $\mathrm{kg}$ of iron [2]. The low tech-low cost" intervention of delayed cord clamping can reduce anemia in infancy by enhancing placentalinfant transfusion at birth. Delayed cord clamping (DCC), in which the cord is clamped after a short delay after birth, and umbilical cord milking (UCM), in which cord blood is stripped or milked toward the baby, have been shown to prevent anemia in infants [3].

These procedures allow the transfer of additional blood volume and hemoglobin ( $\mathrm{Hb} \%$ ) from the placenta to the neonate. This process can improve the infant's iron stores, which may be of particular value in settings in which nutrition is poor [4]. However, a recent meta-analysis reported that delayed cord clamping is only marginally beneficial in reducing anemia in term neonates 
[5]. Moreover, there are concerns about delayed initiation of resuscitation and increased incidence of hypothermia among preterm neonates undergoing these procedures [6]. Also, the risk of maternal bleeding makes a delay in cord clamping at the time of cesarean section challenging [3].

One clinical trial and a secondary analysis from the same trial have compared milking of a $20 \mathrm{~cm}$ segment of the umbilical cord versus immediate umbilical cord clamping on preterm singleton infants born ( $>34$ weeks ) of gestation. Significant findings in the clinical study included higher initial Hb concentration, mean systemic blood pressure, reduced need for blood transfusion and higher urine output during the first 72 hours in the group that underwent umbilical cord milking compared with the group that underwent umbilical cord clamping. Also the group that underwent umbilical cord milking required a shorter duration of supplemental oxygen and mechanical ventilation [7].

Recent studies have demonstrated that UCM and DCC result in comparable increases in $\mathrm{Hb}$ in premature neonates. However, there are insufficient data about the effect of UCM in full-term neonates. The aim of the present will be to investigate the effects of umbilical cord milking in term (gestational age $\geq 37-40+6$ weeks) and near term infants (gestational age $>34-36+6$ weeks) as regard hematological values, incidence of anemia and hemodynamics [8].

\section{Patients and methods}

This is randomized, controlled clinical trial study conducted at Obstetrics and Gynecology department of Suez Canal University hospitals among all pregnant women of fetal age > 34 weeks for cesarean delivery and randomly divided into two groups:

1) Study group: enrolled neonates were allocated to umbilical cord milking technique.

2) Control group: enrolled neonates were allocated to early umbilical cord clamping without milking technique.

Exclusion criteria include had Infants with congenital anomalies, intrauterine growth restriction, Infants with short umbilical cord length $(<25 \mathrm{~cm})$, Delivery by cesarean section for fetal distress, Rhesus factor negative mothers, Cord prolapsed, Hydropesfetalis, Placenta previa, Placental abruption, Cord abnormalities as true knots, multiple gestation and Women with chronic medical illness (diabetes mellitus, Hypertension, cardiac diseases) or pregnancy related illness (gestational diabetes mellitus, preeclampsia). And this study estimated sample size was: $n=400$ (200 patients for each group).

\section{Study procedure}

An informed written consent was obtained from each participant before enrollment in the study. All enrolled women before lower uterine segment cesarean section delivery, were subjected to the following:
1) Full history (age, LMP, socioeconomic status)

2) Maternal weight

3) Maternal high and then BMI

4) Maternal hemoglobin

5) History of medical disorders, history of anemia, and history of antenatal iron supplementation and

6) Gestational age based on date of last menstrual period and documented and proved by first trimester ultrasonographic examination.

In all cases after birth, the neonates were held on the thighs of mother in cesarean section while the umbilical cord was cut and clamped.

\section{In the study group}

The cord was cut at approximately $25 \mathrm{~cm}$ of length from umbilical stump within 30 seconds of birth (early clamping). Then the neonate was placed under the radiant warmer. The umbilical cord was raised and milked from the cut end toward infant 3 times with speed at $10 \mathrm{~cm} / \mathrm{sec}$, and then clamped $2-3 \mathrm{~cm}$ from the umbilical stump.

\section{In the control group}

The umbilical cord was clamped early (within 30 seconds) near the umbilicus and was cut without doing cord milking [3].

After clamping the cord, the neonates of both groups were received the routine care by the attending pediatrician according to standard protocols of neonatal post-delivery newborn care [9].

All neonates of both groups were evaluated for the following:

a) Before discharge of mother and infant hemoglobin and packed cell volume was measured at first 12 hours and 48 hours of postnatal life.

b) Serum bilirubin was measured at 48 hours of postnatal life.

c) Assessment of hemodynamic parameters of heart rate, respiratory rate and blood pressure in the first 48 hours of postnatal life (30 min, 12 hours and 48 hours).

d) All neonates were followed up till age of six weeks and a follow up visit was scheduled for all infants with evaluation of hemoglobin, and serum ferritin at that visit for assessment of incidence of anemia.

\section{Statistical analysis}

Gathered data was processed using SPSS version 15 (SPSS Inc., Chicago, IL, USA) 21st edition (2013). Quantitative data was expressed as mean $\pm \mathrm{SD}$ while qualitative data was expressed as numbers and percentages (\%). Student $t$ test and ANOVA test was used to test significance of difference for quantitative variables 
and Chi Square were used to test significance of difference for qualitative variables. A probability value of $p$-value $<0.05$ was considered statistically significant.

\section{Results}

As shown in (Table1) there were not significant differences in the baseline demographic characteristics of two groups. Most of maternal age was $<35$ years $(64 \%$ in study group \& $56 \%$ in control group), were house wife ( $93.5 \%$ in study group $\& 89.5 \%$ in control group) and lived in Urban (66\%in study group \& 56\% in control group). Most of the mothers in this study their socioeconomic status were moderate $53 \%$ of mothers in early cord clamping group and $48 \%$ of mothers milking group and it was no significant difference in both groups.

Table1: Socio-demographic characteristics of the study and control groups $(n=400)$.

\begin{tabular}{|c|c|c|c|c|}
\hline \multicolumn{2}{|c|}{ Characteristics } & Study group $(n=200)$ Mean \pm SD No. $(\%)$ & Control group $(n=200)$ Mean \pm SD No. $(\%)$ & p-value \\
\hline \multirow{3}{*}{ Age (years) } & $<35$ years & $128(64.0)$ & $112(56.0)$ & \multirow{3}{*}{$0.378^{* b}$} \\
\hline & 35-39 years & $62(31.0)$ & $76(38.0)$ & \\
\hline & $\geq 40$ years & $10(5.0)$ & $12(6.0)$ & \\
\hline \multirow{6}{*}{ Education } & Illiterate & $16(8.0)$ & $14(7.0)$ & \multirow{6}{*}{$0.458^{* b}$} \\
\hline & primary & $68(34.0)$ & $72(36.0)$ & \\
\hline & secondary & $90(45.0)$ & $88(44.0)$ & \\
\hline & High school & $16(8.0)$ & $18(9.0)$ & \\
\hline & University & $10(5.0)$ & $8(4.0)$ & \\
\hline & Postgraduate & 0 & 0 & \\
\hline \multirow{2}{*}{ Occupation } & Yes & $13(6.5)$ & $21(10.5)$ & \multirow{2}{*}{$0.102^{\mathrm{b}}$} \\
\hline & No & $187(93.5)$ & $179(89.5)$ & \\
\hline \multirow{2}{*}{ Residency } & Rural & $68(34.0)$ & $88(44.0)$ & \multirow{2}{*}{$0.026^{* \mathrm{~b}}$} \\
\hline & Urban & $132(66.0)$ & $112(56.0)$ & \\
\hline \multirow{3}{*}{$\begin{array}{c}\text { Socioeconomic } \\
\text { level }\end{array}$} & Low & $64(32.0)$ & $58(29.0)$ & \multirow{3}{*}{$0.606^{\mathrm{b}}$} \\
\hline & Middle & $96(48.0)$ & $106(53.0)$ & \\
\hline & High & $40(20.0)$ & $36(18.0)$ & \\
\hline Weight (kg) & & $88.0 \pm 14.8$ & $83.8 \pm 17.8$ & $0.161^{* a}$ \\
\hline Height & & $163.0 \pm 5.9$ & $161.9 \pm 15.7$ & $0.683^{* a}$ \\
\hline \multirow{3}{*}{$\begin{array}{l}\text { BMI categories } \\
\mathrm{kg} / \mathrm{m}\end{array}$} & Normal<25 & $4(2.0)$ & $4(2.0)$ & \multirow{3}{*}{$0.276^{* \mathrm{~b}}$} \\
\hline & $\begin{array}{c}\text { Overweight } \\
25-29\end{array}$ & $52(26.0)$ & $60(30.0)$ & \\
\hline & Obese $\geq 30$ & $144(73.0)$ & $136(68.0)$ & \\
\hline
\end{tabular}

${ }^{*}$ Statistically significant at $\mathrm{P}<0.05$ and $95 \%$ confidence level

aMann Whitney $U$ test

bChi square Test

As shown in (Table 2) there were significant difference in number of neonates born to Primi mothers and Multi parous mothers between study group and control group. Most of mothers included in the study previous delivery by lower segment caesarean section (81\% in study group and $63 \%$ in control group). And also there were no significant differences in the maternal $\mathrm{Hb}$ level but mothers in both groups (66\% \&59\% respectively) were taken iron Table 2: Comparison of study \& control groups regarding obstetric history $(n=400)$.

\begin{tabular}{|c|c|c|c|c|}
\hline \multicolumn{2}{|c|}{ Characteristics } & Study group (n= 200) No. (\%) & Control group (n= 200) No. (\%) & p-value \\
\hline \multirow{3}{*}{ Gravidity } & Primigravida & $42(21.0)$ & $14(7.0)$ & $0.001^{* b}$ \\
\cline { 2 - 5 } & Multigravida & $158(79.0)$ & $186(93.0)$ & $<2(38.7)$ \\
\hline \multirow{2}{*}{ Type of previous delivery } & Vaginal & $30(19.0)$ & $114(61.3)$ & $<0.001^{* b}$ \\
\cline { 2 - 5 } & C.S & $128(81.0)$ & \\
\hline
\end{tabular}

supplement during pregnancy. Sixty four percent of neonates in the study group were males compared to $56.0 \%$ in control group. Also the mean \pm SD of neonate birth weight was $3058.4 \pm 483.5$ vs. $2951.3 \pm 497.5$ in study and control groups. Moreover the mean \pm SD of gestational age was $37.9 \pm 2.0$ vs. $37.6 \pm 1.9$ in study and control groups (Table 3). 


\begin{tabular}{|c|c|c|c|c|}
\hline \multirow{3}{*}{ Maternal Hb \% } & $<9 \mathrm{gm} / \mathrm{dl}$ & $4(2.0)$ & $3(1.5)$ & $0.556^{* \mathrm{~b}}$ \\
\cline { 2 - 4 } & $9-11 \mathrm{gm} / \mathrm{dl}$ & $159(79.5)$ & $34(17)$ & $162(81.5)$ \\
\cline { 2 - 5 } & $\geq 11 \mathrm{gm} / \mathrm{dl}$ & $37(18.5)$ & $118(59.0)$ & $0.148^{\mathrm{b}}$ \\
\hline $\begin{array}{c}\text { Antenatal iron supplemen- } \\
\text { tation }\end{array}$ & & $132(66.0)$ & $200(100 \%)$ & 1 \\
\hline Use of oxytocin & & $200(100 \%)$ & 1 \\
\hline
\end{tabular}

${ }^{*}$ Statistically significant at $\mathrm{P}<0.05$ and $95 \%$ confidence level

bChi square Test

Table 3: Neonatal data of study and control groups $(n=400)$.

\begin{tabular}{|c|c|c|c|c|}
\hline \multicolumn{2}{|c|}{ Characteristics } & Study group $(n=200)$ Mean $\pm S D$ & Control group $(n=200)$ Mean \pm SD & p-value \\
\hline Birth weight (gram) & & $3058.4 \pm(483.5)$ & $2951.3 \pm(497.5)$ & $0.288^{* b}$ \\
\hline \multirow{2}{*}{ Gestational age (weeks) } & & $37.9 \pm 2.0$ & $37.6 \pm 1.9$ & $0.027^{* a}$ \\
\hline & & No. (\%) & No. (\%) & \\
\hline \multirow{2}{*}{ Gestational age (weeks) } & $>34-37$ & $56(28.0)$ & $62(31.0)$ & \multirow{2}{*}{$0.276^{* \mathrm{~b}}$} \\
\hline & $\geq 37-42$ & $144(72.0)$ & $138(69.0)$ & \\
\hline \multirow{2}{*}{ Gender } & Female & $72(36.0)$ & $90(44.0)$ & \multirow{2}{*}{$0.378^{* \mathrm{~b}}$} \\
\hline & Male & $128(64.0)$ & $112(56.0)$ & \\
\hline \multirow{2}{*}{ Apgar score at one min } & Normal & $190(95.0)$ & $196(98.0)$ & \multirow{2}{*}{$0.103^{* b}$} \\
\hline & Fairly low & $10(5.0)$ & $4(2.0)$ & \\
\hline \multirow{2}{*}{ Exclusive breast feeding } & Yes & $187(93.5)$ & $178(89.0)$ & \multirow{2}{*}{$0.102^{*}$} \\
\hline & No & $13(6.5)$ & $22(11.0)$ & \\
\hline
\end{tabular}

*Statistically significant at $\mathrm{P}<0.05$ and $95 \%$ confidence level

bChi-square Test

As shown in (Table 4) there were not significant differences in respiratory distress and oxygen therapy between the study and control groups. No polycythemia was detected during the study in either group. And also none of neonates required admission in hospital or required phototherapy. As shown in (Table 5) at 30 heart rate between the study and control groups. But at 48 hours there were no significant difference in heart rate and respiratory rate between both groups. The mean blood pressure at 30 minutes, 12 hours, and 48 hours after birth was significantly higher but within normal range in the study group. minutes and 12 hours of life, there were significant differences in

Table 4: Comparison of neonatal outcomes between study and control groups $(n=400)$.

\begin{tabular}{|c|c|c|c|c|}
\hline \multicolumn{2}{|l|}{ Characteristics } & Study group $(n=200)$ No. $(\%)$ & Control group $(n=200)$ No. $(\%)$ & p-value \\
\hline \multirow{2}{*}{ Oxygen therapy } & Yes & $10(5.0)$ & $4(2.0)$ & \multirow{2}{*}{$0.103^{* b}$} \\
\hline & No & $190(95.0)$ & $196(98.0)$ & \\
\hline \multirow{2}{*}{ Blood transfusion } & Yes & $0(0,0)$ & $0(0.0)$ & \multirow{2}{*}{ NA } \\
\hline & No & $200(100)$ & $200(100)$ & \\
\hline \multirow{2}{*}{ Intraventricular hemorrhage } & Yes & $0(0,0)$ & $0(0.0)$ & \multirow{2}{*}{ NA } \\
\hline & No & $200(100)$ & $200(100)$ & \\
\hline \multirow{2}{*}{ Mechanical ventilation used } & Yes & $0(0,0)$ & $0(0.0)$ & \multirow{2}{*}{ NA } \\
\hline & No & $200(100)$ & $200(100)$ & \\
\hline \multirow{2}{*}{ Respiratory distress } & Yes & $8(4.0)$ & $6(3.0)$ & \multirow{2}{*}{$0.188^{* \mathrm{~b}}$} \\
\hline & No & $192(96.0)$ & $194(97.0)$ & \\
\hline \multirow{2}{*}{ Jitteriness } & Yes & $0(0,0)$ & $0(0.0)$ & \multirow{2}{*}{ NA } \\
\hline & No & $200(100)$ & $200(100)$ & \\
\hline \multirow{2}{*}{ Death } & Yes & $0(0,0)$ & $0(0.0)$ & \multirow{2}{*}{ NA } \\
\hline & No & $200(100)$ & $200(100)$ & \\
\hline \multirow{2}{*}{ Hospital stay } & Yes & $0(0,0)$ & $0(0.0)$ & \multirow{2}{*}{ NA } \\
\hline & No & $200(100)$ & $200(100)$ & \\
\hline
\end{tabular}




\begin{tabular}{|c|c|c|c|c|}
\hline \multirow{2}{*}{ Phototherapy } & Yes & $0(0,0)$ & $0(0.0)$ & NA \\
\cline { 2 - 5 } & No & $200(100)$ & $0(100)$ & \multirow{2}{*}{ NA } \\
\hline \multirow{2}{*}{ Polycythemia } & Yes & $0(0,0)$ & $200(100)$ & \\
\cline { 2 - 5 } & No & $200(100)$ & \\
\hline
\end{tabular}

*Statistically significant at $\mathrm{P}<0.05$ and $95 \%$ confidence level

bChi-square Test

\section{NA: Not Applicable}

There was elevated of number of neonates who had jaundice but no significant differences between the study and control groups. At 30 minutes of birth there was significant difference pallor as infants less pallor in study group comparable to control group. But at 12 and 48 hours there was no significant difference between both groups (Table 6).

The mean $\mathrm{Hb}$ and PCV at 12 and 48 hours were significantly higher in study group than control group. The mean ferritin and mean $\mathrm{Hb}$ at 6 weeks was higher in study group compared with

control group. Serum bilirubin was slightly elevated in study group from control group.

The mean Hb and PCV at 12 and 48 hours were significantly higher in study group than control group. The mean ferritin and mean $\mathrm{Hb}$ at 6weaks was higher in study group compared with control group. Serum bilirubin was slightly elevated in umbilical cord milking group from early cord clamping group. On subgroup analysis similar findings were observed in term and near term infants (Table 7).

Table 5: Comparison between hemodynamic parameters in study and control groups $(n=400)$.

\begin{tabular}{|c|c|c|c|c|c|c|c|c|}
\hline & & \multicolumn{2}{|c|}{ Overall infants } & \multicolumn{2}{|c|}{ Study group } & \multicolumn{2}{|c|}{ Control group } & \multirow{2}{*}{$\begin{array}{c}P \text { value } \\
\text { for overall } \\
\text { infants }\end{array}$} \\
\hline & & $\begin{array}{l}\text { Study group } \\
\text { Mean } \pm \text { SD }\end{array}$ & $\begin{array}{l}\text { Control } \\
\text { group Mean } \\
\pm \mathrm{SD}\end{array}$ & $\begin{array}{c}\text { Term } \\
(n=144) \\
\text { Mean } \pm \text { SD }\end{array}$ & $\begin{array}{c}\text { Near term } \\
(n=56) \text { Mean } \\
\pm \text { SD }\end{array}$ & $\begin{array}{c}\text { Term } \\
(n=138) \\
\text { Mean } \pm \text { SD }\end{array}$ & $\begin{array}{c}\text { Near term } \\
(n=62) \text { Mean } \\
\pm S D\end{array}$ & \\
\hline \multirow{3}{*}{ Heart rate } & $30 \mathrm{~min}$ & $157.0 \pm 7.2$ & $148.44 \pm 8.3$ & $156.6 \pm 7.6$ & $158.1 \pm 6.6$ & $148.8 \pm 8.9$ & $147.4 \pm 6.2$ & $<0.001^{* a}$ \\
\hline & $12 \mathrm{hr}$ & $153.7 \pm 6.5$ & $151.4 \pm 6.3$ & $153.3 \pm 6.5$ & $154.7 \pm 6.5$ & $151.5 \pm 6.6$ & $151.2 \pm 5.2$ & $<0.001^{* a}$ \\
\hline & $48 \mathrm{hr}$ & $147.2 \pm 6.4$ & $146.9 \pm 8.0$ & $147.5 \pm 6.7$ & $147.1 \pm 5.8$ & $148.0 \pm 7.6$ & $144.6 \pm 8.3$ & $0.566^{\mathrm{a}}$ \\
\hline \multirow{3}{*}{$\begin{array}{l}\text { Respiratory } \\
\text { rate }\end{array}$} & $30 \mathrm{~min}$ & $47.5 \pm 6.7$ & $45.3 \pm 11.1$ & $47.1 \pm 6.3$ & $48.4 \pm 7.6$ & $45.5 \pm 11.3$ & $44.7 \pm 10.9$ & $<0.001^{\mathrm{a}}$ \\
\hline & $12 \mathrm{hr}$ & $47.3 \pm 7.3$ & $47.0 \pm 7.7$ & $47.0 \pm 7.2$ & $48.8 \pm 8.0$ & $46.6 \pm 6.9$ & $47.0 \pm 8.8$ & $0.515^{\mathrm{a}}$ \\
\hline & $48 \mathrm{hr}$ & $45.0 \pm 6.8$ & $44.3 \pm 7.2$ & $44.2 \pm 6.5$ & $47.0 \pm 7.1$ & $44.1 \pm 6.9$ & $44.9 \pm 7.7$ & $0.598^{\mathrm{a}}$ \\
\hline \multirow{3}{*}{$\begin{array}{l}\text { Blood } \\
\text { pressure }\end{array}$} & $30 \mathrm{~min}$ & $51.7 \pm 11.2$ & $48.3 \pm 10.9$ & $51.5 \pm 11.3$ & $53.9 \pm 9.5$ & $47.3 \pm 10.7$ & $49.4 \pm 9.1$ & $<0.05^{* a}$ \\
\hline & $12 \mathrm{hr}$ & $50.2 \pm 10.9$ & $47.4 \pm 9.6$ & $50.3 \pm 10.8$ & $55.2 \pm 9.5$ & $46.1 \pm 9.6$ & $50.4 \pm 9.2$ & $<0.05^{* a}$ \\
\hline & $48 \mathrm{hr}$ & $50.1 \pm 10.6$ & $46.4 \pm 9.1$ & $50.2 \pm 10.8$ & $54.2 \pm 9.3$ & $46.0 \pm 9.5$ & $48.9 \pm 8.1$ & $<0.05^{* a}$ \\
\hline
\end{tabular}

*Statistically significant at $\mathrm{P}<0.05$ and $95 \%$ confidence level

aMann-Whitney

Table 6: Comparison between cyanosis, Jaundice \&pallor in study and control groups $(n=400)$

\begin{tabular}{|c|c|c|c|c|c|c|c|c|}
\hline & & \multicolumn{2}{|c|}{ Overall infants } & \multicolumn{2}{|c|}{ Study group } & \multicolumn{2}{|c|}{ Control group } & \multirow[b]{2}{*}{$\begin{array}{l}\text { P value for } \\
\text { all infants }\end{array}$} \\
\hline & & $\begin{array}{c}\text { Study } \\
\text { group(n=200) } \\
\text { No. }(\%)\end{array}$ & $\begin{array}{c}\text { Control } \\
\text { group(n=200) No. } \\
(\%)\end{array}$ & $\begin{array}{c}\text { Term infant }(\mathrm{n}=144) \\
\text { No. }(\%)\end{array}$ & $\begin{array}{l}\text { Near ter- } \\
\mathrm{m}(\mathrm{n}=56) \text { No. } \\
(\%)\end{array}$ & $\begin{array}{c}\text { Term } \\
(\mathrm{n}=138) \text { No. } \\
(\%)\end{array}$ & $\begin{array}{l}\text { Near ter- } \\
\mathrm{m}(\mathrm{n}=62) \text { No. } \\
\quad(\%)\end{array}$ & \\
\hline \multirow{4}{*}{ Cyanosis } & $30 \mathrm{~min}$ & $44(22.0)$ & $26(13.0)$ & $26(18.1)$ & $18(32.1)$ & $16(11.6)$ & $10(16.1)$ & $0.018^{* \mathrm{~b}}$ \\
\hline & $12 \mathrm{hr}$ & $0(0.0)$ & $2(1.0)$ & $0(0.0)$ & $0(0.0)$ & $0(0.0)$ & $2(3.2)$ & $0.499^{c}$ \\
\hline & $48 \mathrm{hr}$ & $0(0.0)$ & $0(0.0)$ & $0(0.0)$ & $0(0.0)$ & $0(0.0)$ & $0(0.0)$ & NA \\
\hline & $30 \mathrm{~min}$ & $0(0.0)$ & $0(0.0)$ & $0(0.0)$ & $0(0.0)$ & $0(0.0)$ & $0(0.0)$ & NA \\
\hline \multirow{2}{*}{ Jaundice } & $12 \mathrm{hr}$ & $28(14.0)$ & $24(12.0)$ & $18(12.5)$ & $10(17.9)$ & $16(11.6)$ & 8 (12.9) & $0.522^{b}$ \\
\hline & $48 \mathrm{hr}$ & $124(62.0)$ & $106(53.0)$ & $86(59.7)$ & 38 (67.9) & 74 (53.6) & $32(51.6)$ & $0.069^{\mathrm{b}}$ \\
\hline \multirow{3}{*}{ Pallor } & $30 \mathrm{~min}$ & $34(17.0)$ & $52(26.0)$ & $26(18.1)$ & $8(14.3)$ & $40(29.0)$ & $12(19.4)$ & $0.028^{* \mathrm{~b}}$ \\
\hline & $12 \mathrm{hr}$ & $38(19.0)$ & $40(20.0)$ & $26(18.1)$ & $12(21.4)$ & $36(26.1)$ & $4(6.5)$ & $0.801^{b}$ \\
\hline & $48 \mathrm{hr}$ & $0(0.0)$ & $0(0.0)$ & $0(0.0)$ & $0(0.0)$ & $0(0.0)$ & $0(0.0)$ & NA \\
\hline
\end{tabular}

*Statistically significant at $\mathrm{P}<0.05$ and $95 \%$ confidence level

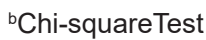

cfisher 


\section{NA: Not Applicable}

Table7: Comparison between hematological parameters in study and control groups $(n=400)$.

\begin{tabular}{|c|c|c|c|c|c|c|c|c|}
\hline & & \multicolumn{2}{|c|}{ Overall infants } & \multicolumn{2}{|c|}{ Study group } & \multicolumn{2}{|c|}{ Control group } & \multirow{2}{*}{$\begin{array}{c}\text { P value } \\
\text { for } \\
\text { overall } \\
\text { infants }\end{array}$} \\
\hline & & $\begin{array}{c}\text { Study } \\
\text { group }(n=200) \\
\text { Mean } \pm \text { SD }\end{array}$ & $\begin{array}{c}\text { Control } \\
\text { group }(n=200) \\
\text { Mean } \pm \text { SD }\end{array}$ & $\begin{array}{c}\text { Term }(n=144) \\
\text { Mean } \pm \text { SD }\end{array}$ & $\begin{array}{l}\text { Near term } \\
(\mathrm{n}=56) \text { Mean } \\
\quad \pm \text { SD }\end{array}$ & $\begin{array}{c}\text { Term }(n=138) \\
\text { Mean } \pm \text { SD }\end{array}$ & $\begin{array}{l}\text { Near term } \\
\quad(n=62) \\
\text { Mean } \pm S D\end{array}$ & \\
\hline \multirow{3}{*}{$\begin{array}{l}\text { Hemoglobin } \\
\text { (gm/dl) }\end{array}$} & $\begin{array}{c}12 \\
\text { hours }\end{array}$ & $16.9 \pm 1.7$ & $16.2 \pm 1.0$ & $16.8 \pm 1.6$ & $17.0 \pm 2.0$ & $16.2 \pm 1.1$ & $16.2 \pm 0.9$ & $<0.001^{\text {*a }}$ \\
\hline & $\begin{array}{c}48 \\
\text { hours }\end{array}$ & $16.9 \pm 1.7$ & $16.2 \pm 1.0$ & $16.8 \pm 1.4$ & $17.0 \pm 2.0$ & $16.2 \pm 1.1$ & $16.2 \pm 0.9$ & $<0.001^{\mathrm{a}}$ \\
\hline & 6 weeks & $15.5 \pm 1.5$ & $15.0 \pm 1.2$ & $15.5 \pm 1.4$ & $15.5 \pm 1.7$ & $14.9 \pm 1.2$ & $15.2 \pm 1.0$ & $0.002^{* a}$ \\
\hline \multirow{2}{*}{$\begin{array}{l}\text { Packed Cell } \\
\text { Volume (\%) }\end{array}$} & $\begin{array}{c}12 \\
\text { hours }\end{array}$ & $53.1 \pm 6.1$ & $51.9 \pm 3.0$ & $52.8 \pm 5.8$ & $53.8 \pm 7.1$ & $51.9 \pm 3.2$ & $52.1 \pm 2.5$ & $0.016^{* a}$ \\
\hline & $\begin{array}{c}48 \\
\text { hours }\end{array}$ & $53.1 \pm 6.1$ & $51.9 \pm 3.0$ & $52.8 \pm 5.8$ & $53.8 \pm 7.1$ & $51.9 \pm 3.2$ & $52.1 \pm 2.5$ & $0.016^{\mathrm{a}}$ \\
\hline Serum bilirubin & $\begin{array}{c}48 \\
\text { hours }\end{array}$ & $7.6 \pm 2.1$ & $6.4 \pm 1.9$ & $7.5 \pm 2.2$ & $7.8 \pm 1.9$ & $6.5 \pm 2.0$ & $6.2 \pm 1.9$ & $<0.001^{* a}$ \\
\hline Ferritin $(\mu \mathrm{g} / \mathrm{ml})$ & 6 weeks & $135.4 \pm 5.8$ & $128.8 \pm 4.5$ & $135.3 \pm 5.5$ & $135.8 \pm 6.4$ & $128.3 \pm 4.9$ & $129.7 \pm 3.4$ & $<0.001^{* a}$ \\
\hline
\end{tabular}

*Statistically significant at $\mathrm{P}<0.05$ and $95 \%$ confidence level

\section{*aMann-Whitney}

\section{Discussion}

This study was aimed at assessment of umbilical cord milking on certain outcome of term and preterm infants. In fact umbilical cord milking is believed to be a simple and safe procedure which agreed with all studies. J. Matern 2017 had showed that UCM was emerged as a safe, quick alternative to DCC and more advantageous especially among premature infants and those delivered by cesarean section [10]. As recent evidence started to underline the importance of placental transfusion in the neonate outcomes, clinical trials analyzed the role of each individual triad component promoted in the past by the WHO for the active management of the third stage of labour. As a result, the practice of immediate cord clamping was excluded by the WHO guidelines in 2012, and cord traction was defined as optional $[11,12,13]$. Placental transfusion is the transfer of placental blood to the infant during the first few seconds after birth [14]. This procedure is associated with lower rates of mortality in preterm infants and with the prevention of iron deficiency anemia in term infants $[10,15]$. In present study infants in umbilical cord milking group had higher hemoglobin values at12, 48 hours and 6 weeks $(16.9,16.9 \& 15.5 \mathrm{gm} / \mathrm{dl})$ as compared with early cord clamping group (16.2,16.2 \& 15,0 gm/dl),indicating an increased amount of placental blood transfer in Umbilical cord milking group and this result agreed with Katheria AC et al [14] . Also in present study, infants in subgroup of umbilical cord milking whether term or preterm infants had higher hemoglobin values as compared with early cord clamping group which were agreed with Upadhyay et al but with different values .

Where in present study, the term infants, hemoglobin values at 12, 48 hours and 6 weeks were $(16.8,16.8 \& 15.5 \mathrm{gm} / \mathrm{dl})$ in umbilical cord milking group as compared with non- milking group
(16.2, 16.2\& $14.9 \mathrm{gm} / \mathrm{dl})$. And in near term infant, hemoglobin values at 12,48 hours and 6 weeks were $(17.0,17.0$ \&15.5 gm/ dl) in umbilical cord milking group as compared with non- milking group $(16.2,16.2 \& 15.2 \mathrm{gm} / \mathrm{dl})$. The results indicated that there was significantly difference between the study and control group as decreased the incidence of anemia in term and near term infants. In 2013 Amit Upadhyay et al [3] had showed that mean hemoglobin at 12,48 hours \& 6 weeks was higher in the umbilical cord milking group $(15.1,11.9 \& 11.9 \mathrm{gm} / \mathrm{dl})$ compared to immediate cord clamping group $(13.5,10.8 \& 10.8 \mathrm{gm} / \mathrm{dl})$.

In this study the mean $\mathrm{Hb}$ soon after birth was low and after 48 hours was more drop this possible was due to poor maternal health and a high prevalence of maternal anemia (52\%) [3]. Katheria AC 2015 UCM may be a more efficient technique to improve blood volume in premature infants which agreed with the present study but with different in the level range [16]. In 2017 Song et al had showed that umbilical cord milking group with increased significantly associated with increased $\mathrm{Hb}$ level of infants at initials, increased blood volume, decreased the need for blood transfusion so improve preterm infant [17]. Katheria A 2018 Even if published data on UCM positive effects are encouraging, suggesting that UCM may be the most effective method to provide placental transfusions in infants requiring resuscitation, evidence on which category of newborns would benefit the most from UCM is still inadequate [18] but this point was not included in the present study due to exclude infants requiring resuscitation. In a study Dr Rahul Vashistha in 2019 showed that milking group had higher hemoglobin values at 30 min, 48 hours and 6 weeks $(17.28,15.6 \& 15.14)$ as compared with delayed clamping group (16.3, 15.15\&14.7), indicating an increased amount of placental blood transfer in Umbilical cord milking group, this relationship also indicate that the procedure of milking four times guarantees the transfer of extra amount 
of placental blood into the infants when compared to delayed clamping [19]. And in this study the range between study and control groups were small because the two groups had placental blood transfusion. At the same time their range similar to the range of present study in umbilical cord milking group. And in a study Leal V, et al in 2019 Initial hemoglobin was significantly higher in the milking group by $1.675 \mathrm{~g} / \mathrm{dl}(\mathrm{p}<0.05)$ and initial hematocrit by $5.36 \%(p<0.05)$ [20]. According to Italian recommendations in case of CS term newborns, if DCC cannot be performed, UCM may be considered as an alternative procedure with the purpose of increasing haemoglobin levels in postnatal period and iron reserves in the following weeks [21]. In this scenario, this practice rapidity of execution may offer a significant advantage in reducing maternal blood loss. From the previous studies found that hemoglobin level in umbilical cord milking was significant high which agreed with the present study with variation of range.

In present study infants in umbilical cord milking group had higher ferritin values at 6 weeks $(135.4 \mu \mathrm{g} / \mathrm{ml})$ as compared with early cord clamping group $(128.8 \mu \mathrm{g} / \mathrm{ml})$ which were significant. Where in term infants, ferritin values at 6 weeks $(135.3 \mu \mathrm{g} / \mathrm{ml})$ in umbilical cord milking group as compared with non- milking group $(128.3 \mu \mathrm{g} / \mathrm{ml})$.

And in near term infant, ferritin values at 6 weeks $(135.8 \mu \mathrm{g} /$ $\mathrm{ml}$ ) in umbilical cord milking group as compared with early cord clamping group (129.7 $\mu \mathrm{g} / \mathrm{ml})$. These results were significant and indicated to improve iron stores in umbilical cord milking.

Amit Upadhayay et al 2013 [3] Serum ferritin at 6 weeks was significantly higher in milking group $(355.9 \mu \mathrm{g} / \mathrm{L})$ than in immediate clamping group $(177.5 \mu \mathrm{g} / \mathrm{L})$. So they reported a significantly favourable effect on serum ferritin in term and near term infants from umbilical cord milking compared to immediate cord clamping group at 6 weeks of life [3]. And this agreed with the present study but there were more drop in ferritin value in study Upadhayay between the two groups which might be due to poor maternal nutrition. In 2015 Jaiswal showed that Mean serum ferritin $(134.0 \mu \mathrm{g} / \mathrm{L} \pm 89.8)$ and mean hemoglobin $(11.0 \mathrm{gm} / \mathrm{dl} \pm 2.4)$ in UCM group was comparable to mean serum ferritin $(142.7 \mu \mathrm{g} / \mathrm{L}$ $\pm 87.1)$ and hemoglobin (11.3 gm/dl \pm 2.6$)$ in DCC group at 6 weeks of age [22] and this agreed with the present study.

In a study Dr Rahul Vashistha [19] in 2019 showed that milking group had slightly higher ferritin values at 6 weeks $(133.53 \mu \mathrm{g} / \mathrm{L})$ as compared with delayed cord clamping group $(131.64 \mu \mathrm{g} / \mathrm{L})$ in term infants. But it showed that umbilical cord milking was the method of rapid transfer of cord blood to infant [19] and this also agreed with the present study. In present study no polycythemia was recorded in both the groups. These results are similar to Amit Upadhayay et al study in which none of the infants had polycythemia [3]. And in study Ceriani Cernadas et al also showed that there was no difference in polycythemia between the immediate and delayed cord clamping groups [1].

In present study infants in umbilical cord milking group had higher bilirubin at 48 hours as compared with early cord clamping group in term $(7.5 \& 6.5 \mathrm{mg} / \mathrm{dl})$ and preterm infants $(7.8$ $\& 6.2 \mathrm{mg} / \mathrm{dl}$ ). But no significant difference was founded in this study in relation to the development of jaundice and there was no requirement of phototherapy among the two groups. In 2013, Upadhyay observed that infants in umbilical cord milking group as compared to cord clamping among term and preterm no significant difference in serum bilirubin levels, while none of infants required phototherapy [3] and this study agreed with the present study. But the present study did not agree with Dang D and Jaiswal P which found that umbilical cord milking group did not show any increase in serum bilirubin or need for phototherapy in term and near term infants otherwise this results might be due to that umbilical cord milking decreased serum bilirubin in premature infants. Because they had fewer packed RBCs transfusion, so less RBCs destruction and decreased bilirubin level in their blood $[22,23]$

But Leal et al 2019 Peak serum bilirubin was similar in both groups $(11,097 \pm 3.21$ vs. $11,247 \pm 3.56 \mathrm{mg} / \mathrm{dl}, \mathrm{p}=0.837)$. Phototherapy requirements were higher in the milking group in preterm infant [20]. And this study did not agree with present study too. In present study significant difference was observed in heart rate and respiratory rate at $30 \mathrm{~min}$ of birth where they were elevated in umbilical cord milking group comparable to non- milking group indicated improvement in the physiological parameters but after that there was no significant difference was observed at 12 and 48 hours in both groups.

And this result might be due to the neonate at $30 \mathrm{~min}$ after birth was more stress and after that they were more stable. Upadhyay 2013, there was no significant difference in heart rate and respiratory rate in term and preterm infants in both groups [3]. Such as similar to the present study at 12 and 48 hours in both groups.

\section{Conclusion}

Umbilical cord milking is a safe procedure. Umbilical cord milking provides a greater placental transfusion, as demonstrated by higher $\mathrm{Hb}$ of umbilical cord group after birth. Umbilical cord milking improves $\mathrm{Hb}$ level and iron status at 6 weeks in term and preterm infants. Umbilical cord milking is more effective than non- milking cord in protection of anemia in term and near term infants. Umbilical cord milking does not produce significant hemodynamic disturbances. Umbilical cord milking may cause slightly hyperbilirubinemia otherwise not need to phototherapy.

\section{Acknowledgement}

None.

\section{Conflicts of Interest}




\section{No Conflicts of Interest.}

\section{References}

1. Ceriani Cernadas JM, Carroli G, Pellegrini L, Otano L, Ferreira M, et al. (2006) The effect of timing of cord clamping on neonatal venous hematocrit values and clinical outcome at term: A randomized controlled trial. Pediatrics 117(4): e779-e786.

2. McAdams RM, Fay E, Delaney S (2018) Whole blood volumes associated with milking intact and cut umbilical cords in term newborns. J Perinatol 38(3): 245-250.

3. Upadhyay A, Gothwal S, Parihar R, Garg A, Gupta A, et al. (2013) Effect of umbilical cord milking in term and near term infants: randomized control trial. Am Journal of Obstet Gynecol 208(2): 120.e1-e6.

4. McDonald SJ, Middleton P, Therese Dowswell, Peter S Morris (2013) Effect of timing of umbilical cord clamping of term infants on maternal and neonatal outcomes. Cochrane Database Syst Rev 3(7): CD004074.

5. Methew JL (2011) Timing of umbilical cord clamping in term and preterm deliveries and infant and maternal outcome: a systematic review of randomized controlled trials. Indian Paediatr 48(2): 123-129.

6. Hosono S, Mugishima H, Kitamura T, Inami I, Fujita H, et al. (2008) Effect of haemoglobin on transfusion and neonatal adaptation in extremely low birth weight infants. Pediatr Int 50(3): 306-311.

7. Hosono S, Mugishima H, Fujita H, Hosono A, Minato M, et al. (2008) Umbilical cord milking reduces the need for red cell transfusions and improves neonatal adaptation in infants born less than 29 weeks' gestation: a randomized controlled trial. Arch Dis child Fetal Neonatal ed 93(1): F14-19.

8. Rabe H, Jewison A, Alvarez RF, Crook D, Stitition D, et al. (2011) Milking compared with delayed cord clamping to increase placental transfusion in preterm neonates: a randomized controlled trial. Obstet Gynecol 117: F 205-211.

9. Mercer JS, Erickson Owens D, Graves B, Haley M (2007) Evidence-Based Practices for the Fetal to Newborn Transition. J Midwifery Women's Health 52(3): 262-272

10. Azif Safarulla (2017) A review of benefits of cord milking over delayed cord clamping in the preterm infant and future directions of research. J Matern Fetal Neonatal Med 30(24): 2966-2973.

11. American College of Obstetricians and Gynecologists (2006) ACOG practice bulletin: clinical management guidelines for obstetrician- gynecologists number 76, October 2006: postpartum hemorrhage. Obstet Gynecol 108(4): 1039-1047.

12. (2012) WHO Guidelines Approved by the Guidelines Review Committee. Guidelines on Basic Newborn Resuscitation Geneva: World Health Organization.

13. Say L, Chou D, Gemmill A,Tuncalp O, Moller AB, et al. (2014) Global causes of maternal death: a WHO systematic analysis. Lancet Glob Health 2(6): e323-e333.

14. Katheria AC, Lakshminrusimha S, Rabe H, McAdams R, Mercer JS (2017) Placental transfusion: A review. Journal of Perinatology 37(2): 105-111.

15. Agarwal S, Jaiswal V, Singh D, Jaiswal P, Garg A (2016) Randomised control trial showed that delayed cord clamping and milking resulted in no significant differences in iron stores and physical growth parameters at one year of age. Acta Paediatr 105(11): e526-e530.

16. Katheria AC, Truong G, Cousins L, Oshiro B, Finer NN (2015) Umbilical cord milking versus delayed cord clamping in preterm infants. Pediatrics 136(1): 61-69.

17. Song SY, Kim Y, Kang BH, Yoo HJ, Lee M (2017) Safety of umbilical cord milking in very preterm neonates: a randomized controlled study. Obstet Gynecol Sci 60(6): 527-534

18. Katheria A, Mercer J, Brown M, Rich W, Baker K, et al. (2018) Umbilical cord milking at birth for term newborns with acidosis: Neonatal outcomes. J Perinatol 38(3): 240-244.

19. Rahul V, Manish A, Yogesh G (2019) A Study on Umblical Cord Milking Vs Delayed Cord Clamping on Hematological Parameters At 6 Weeks of Life in Term Neonates. 6: 05-08.

20. Leal V, Pamplona Bueno L, Cabanillas Vilaplana L, Nicolas Montero E, Martin Blanco M, et al. (2019) Effect of milking maneuver in preterm infants: a randomized controlled trial. Fetal diagnosis and Therapy. 45(1): 57-61.

21. Perrone B, Ghirardello S (2017) Placental transfusion strategies in Italy: A nationwide survey of tertiary-care delivery wards. Am J Perinatol 34(7): 722-728.

22. Jaiswal P, Upadhyay A, Gothwal S, Singh D, Dubey K, (2015) Comparison of two types of intervention to enhance placental redistribution in term infants: randomized control trial. Eur J Pediatr 174(9): 1159-1167.

23. Dang D, Zhang C, Shi S, Mu X, Lv X, et al. (2015) Umbilical cord milking reduces need for red cell transfusions and improves neonatal adaptation 